\title{
Association of Southeast Asian Nations University Network Framework for Women Empowerment in Academe
}

\author{
Dr. Vladimir T. Tamayo
}

\begin{abstract}
This study is anchored on the $21^{\text {st }}$ Century Skills Framework of the Association of South East Asian Nation University Network (AUN). AUN has been an advocate of the $21^{\text {st }}$ century education movement from its inception and visions to empower education leaders to move forward in their own practice. Two decades ago, AUN helped established the Partnership for $21^{\text {st }}$ Century Skills (P21) highlighting 18 different skills. However, over the years, it became clear that the framework was too long and complicated. To resolve this issue, leaders of different specializations were interviewed to determine which of the $21^{\text {st }}$ century skills were the most important.
\end{abstract}

Keywords - collaboration, communication, critical thinking, and creativity.

\section{INTRODUCTION}

For decades, the progress of women advancing in higher education careers has been quite evident. However, there is still a long road to travel. Women remain underrepresented in academic leadership and must exercise professional growth to foster their own advancement and challenging inequities (Bracken et al., 2009). Further, it takes the view that gender inequity is embedded in organizational culture, and therefore the academe must focus on proactive strategies to advance gender equity in academic leadership, such as providing professional development, creating opportunities for experiential learning, encouraging mentors to support and coach more women as they work to advance within administrative roles.

According to Anderson and Jefferson (2017), there was near unanimity that four skills are of great importance which $21^{\text {st }}$ century leaders need to possess in transforming schools: the "Four Cs": collaboration, communication, critical thinking, and creativity.

Specifically, collaborative skill is the willingness to work with all members of the academe. Leaders in the academe must give everyone a voice that will empower them to take ownership of the problem, and more importantly, the solution. A collaborative leader has five qualities: willing to take risks, eager to listen to others, passionate for the cause, optimistic about the future, and able to share knowledge, power, and credit.

Communication skill is the ability to communicate with people, and select methods that allow the greatest expression of his or her thoughts and feelings, and are appropriate for the intended audience. Communication skills include essential element: listening for the message, complimenting people, delegating tasks clearly, and managing meetings with people within the organization.

Furthermore, critical thinking skill is the ability to think clearly and rationally, understanding the logical connection between ideas. It includes problem solving skills which help a leader in synthesizing possible solutions to a problem. A leader with critical thinking skills can: understand the link between ideas, determine the importance and relevance of arguments and ideas, recognize, build and appraise arguments, identify consistencies and errors in reasoning, approach problems in a consistent and systematic way, and reflect on the justification of their own assumptions, beliefs and values. In addition, leaders need to move away from the step by step approach to problem solving that is ingrained in current practices.

Finally, creative skill is more than just artistic talent. It is the ability to transcend ideas, rules, patterns, and relationships to create meaningful ideas, forms, methods and interpretations that have value. 
It is along with the view that this study was conducted. Determining the 21 st century skills of women leaders may lead to the empowerment of their leadership skills and the entire academe as a whole.

\section{METHODOLOGY}

The study used Descriptive-co-relational research which includes naturalistic observation, case studies and surveys (Weiten, 2012). Its main concern is to describe patterns of behavior and discover links or associations between variables. Further, the goal is the acquisition of factual, accurate and systematic data that can be used in averages, frequencies and similar statistical calculations

\section{RESULTS AND DISCUSSIONS}

The first specific problem posted in Chapter I dealt with the profile of the women leaders in the academe as to age, civil status, highest educational attainment, academic rank, length of service as leader, and leadership trainings attended for the last three years.After administering the questionnaires and tabulating the respondents' profile and their $21^{\text {st }}$ century leadership skills, the findings are summarized as follows:

\section{Respondents' Profile}

1.1 Age: The age level with the highest frequency was 4046 years old and the lowest frequency was 33-39 years old.

1.2 Civil Status: The total number of respondents was dominated by 21 married women leaders.

1.3 Educational Attainment: Twenty-two of them were doctorate degree holders.

1.4 Academic Rank: Out of 28 respondents, 20 of them held professorial ranks.

1.5 Length of Service: The study was dominated by 15 women leaders who spent 15 years and above in the service.

1.6 Leadership Trainings or Seminars Attended for the Last Three Years: Seminars attended on the National Level ranked 1 as the highest number of seminars attended while the Local Level ranked 4 as the least number of seminars attended by the respondents.

\section{2. $21^{\text {st }}$ Century Leadership Skills}

2.1 Collaborative Leadership Skills: The item "encourage people an active role in decision making about matters that affect them" obtained the highest weighted mean of 4.00 with a verbal description of "Always" while the item "use influence to produce results whenever possible" obtained the lowest weighted mean of 2.96 with a verbal description of "Often". The average weighted mean of Collaborative Skills is 3.69 and is described as "Always".

2.2 Communication Leadership Skills: The item statement "am able to conduct meetings in a democratic way" earned the highest weighted mean of 3.96 with a verbal description of "Always" while the item statement "tend to do more talking than others in conversations" earned the lowest weighted mean of 2.39 with a verbal description of "Sometimes". The average weighted mean of Communication Leadership Skills is 3.55 and is described as "Always".

2.3 Critical Thinking Skills: The item statement "analyze other people's ideas objectively, by evaluating both advantages and disadvantages" got the highest weighted mean of 3.93 with a verbal description of "Always" while the item statement "relax and focus again on my regular duties after my solution is implemented" got the lowest weighted mean of 3.36 with a verbal description of "Always". The average weighted mean of Critical Thinking Leadership Skills is 3.73 and is described as "Always".

2.4 Creative Leadership Skills: The item statement "believe that my creativity comes from careful planning and forethought obtained the highest weighted mean of 3.89 and is verbally described as "Always" while the item statement "become creative when I am emotionally moved" obtained the lowest weighted mean of 2.46 and is verbally described as "Sometimes". The average weighted mean of Creative Leadership Skills is 3.32 and is described as "Always".

Among the four leadership skills, Critical Thinking Skills obtained the highest weighted mean of 3.73 and is described as "Always" while Creative Skills obtained the lowest weighted mean of 3.22 and is described as "Often".

\section{Relationship between Profile of the Respondents and their Leadership Skills}

The result of correlation analysis between profile of the respondents and their $21^{\text {st }}$ century leadership skills shows that among the profile variables, length of service was the only variable that has Pearson correlation coefficients of .487 and .386 when tested with both collaborative and communication leadership skills thus resulted to a significance of .009 and .042 , respectively. Also, length of service is found to have Pearson correlation 
coefficient of .387 with the over-all leadership skills, Further analyses were made to verify the result of the test (see Appendix C) using stepwise regression analysis but the same results were obtained. Considering the number of profile variables correlated with the leadership skills of the respondents, the researcher cannot reject the hypothesis of the study. Therefore, there is no significant relationship between profile of the respondents and their $21^{\text {st }}$ century leadership skills.

4. Proposed Activities to Empower the $21^{\text {st }}$ Century Skills of Women Leaders in the Academe was prepared by the researcher.

\section{CONCLUSIONS}

Based on the findings of the study, the following conclusions were drawn:

1. The respondents were in the age of early and late 40's, majority were married and holders of doctorate degree, with academic rank of Professor, have spent 15 years and above in service as leaders, most of them attended seminar or training in the National Level.

2. Based on the summary of leadership skills, women leaders in the academe were inclined to be critical thinkers while they needed to be empowered in their creative leadership skills.

3. Except for age, civil status, educational attainment, academic rank and trainings attended, only length of service could predict the kind of leadership skills women in the academe may employ in terms of collaboration and communication.

4. The proposed activities were developed to empower $21^{\text {st }}$ century leadership skills of women in the academe. The proposed activities were designed based on the findings of the study, following its content will empower women leaders reach their fullest potential in leadership.

\section{RECOMMENDATIONS}

In the light of the above conclusion, the following recommendations are offered:

1. Women presidents, vice presidents, and deans may attend different international leadership-related trainings to empower their $21^{\text {st }}$ century leadership skills and eventually improve their functions as leaders in the academe;
2. A leadership enhancement activities specifically for women administrators may be conducted to empower their leadership skills and improve their effectiveness by developing their knowledge, skills and attitudes in performing their function as leaders in the academe. Also, an organization intended for women leaders in the academe may be put up to strengthen their $21^{\text {st }}$ century leadership skills for a better relationship with all the stakeholders of the schools;

3. The proposed activities may be used as basis for the planning of trainings, programs and activities that may empower the $21^{\text {st }}$ century leadership skills of women leaders in the academe; and

4. Further researches on the $21^{\text {st }}$ century leadership skills of women leaders may be expanded to analyze the impact of women leadership in the academe.

\section{REFERENCES}

[1] Bracken S. J. et al. (2009).Women in Academic Leadership: Professional Strategies, Personal Choices. Retrieved from https://books.google.com.ph/books?isbn $=1579221890 \quad$ on July 14, 2018.

[2] Hassel, H., Cole, K. (2017). Surviving Sexism in Academia: Strategies for Feminist Leadership.Retrieved from https://books.google.com.ph/books?isbn=1315523205 on July 14, 2018.

[3] Denmark, F. \&Paludi, M. A. (2008). Psychology of Women: A Handbook of Issues and Theories.

[4] Derr, C. B. et al. (2008). Cross Cultural Approaches To Women Leadership.

[5] Martin, J. et al. (2008). Managing Resources for School Improvement.

[6] Reynolds, C. (2012). Women and School Leadership: International Perspectives. Retrieved from https://books.google.com.ph/books?isbn=0791488918 on July 14, 2018.

[7] Weiten, W. (2012).Themes and Variations.Retrieved from https://books.google.com/books?isbn=1562865021 on October 19, 2018 